\author{
${ }^{1}$ Zh.K. Akasheva*, ${ }^{1,2}$ D.A. Bolysbek, ${ }^{1}$ B.K. Assilbekov, ${ }^{1,2}$ A.K. Yergesh, ${ }^{1,2}$ A.Ye. Zhanseit \\ ${ }^{1}$ Satbayev University, Almaty, Kazakhstan \\ ${ }^{2}$ al-Farabi Kazakh National University, Almaty, Kazakhstan \\ *e-mail: zhibek_akasheva@mail.ru
}

\title{
PORE-NETWORK MODELING AND DETERMINATION OF ROCK AND TWO-PHASE FLUID FLOW PROPERTIES
}

\begin{abstract}
Pore-scale modeling is becoming widely applied in the oil industry. The objective of porescale imaging and modeling is to predict the properties of multiphase flow in porous media. Pore-network model construction of geologically realistic samples and determination of rock and two-phase fluid flow properties are described and discussed in this paper. Pore-network models were constructed using published micro-computed tomography images of different rock samples. Effective porosity, average absolute permeability, capillary pressure, tortuosity (in 3 directions), and relative permeability were calculated for 2 types of displacement (drainage and imbibition). Avizo ${ }^{\circledR}$ Software and two-phase code were used for volume rendering of rock samples and calculations of rock and two-phase fluid flow properties, since it is a valuable and reliable tool for prediction of petrophysical properties and has advances in visualization of the pore space. Created 3D models of core samples based on micro-computed tomography scan data will allow oil and oilfield service companies to create a digital core database on a computer instead of storing physical cores in warehouses, which in turn greatly facilitates access to cores for further work with them.

Key words: pore network model, direct numerical simulation, micro-computed tomography, porosity, absolute permeability, relative permeability, pore size distribution, tortuosity, capillary pressure
\end{abstract}

Introduction. Nowadays pore-scale imaging and modeling allow to replace (at least partly) expensive and time-consuming laboratory experiments. Pore-network models require extensive processing (network extraction) to discretize the imaged irregular pore space into simple geometrical objects (nodes and bonds). Then, simplified versions of the conservation laws are solved within this discretized representation using effective parameters for each pore object [1].

Image acquisition (voxelization, noise, blurring) and image processing (filtering, segmentation, coarsening) precede pore-network extraction. In network modeling the void space of a rock is represented at the microscopic scale by a lattice of pores connected by throats. The pore and throat size distributions will also affect the estimated macroscopic properties [2].

For porous materials, permeability is the macroscopic parameter of basic practical interest, and its measurement is important to predict macro-scale behavior of flows [3]. Macroscopic properties, such as capillary pressure and relative permeability are estimated across the network.

In [4] relative permeabilities were calculated using direct numerical simulation for two-phase fluid flow through a channel. Calculated relative permeabilities (of wetting and non-wetting phases) based on numerical solution of the incompressible Navier-Stokes equations are compared for different mesh sizes, viscosity ratios and surface tension.

Predicting of fluid flow properties in a porous media such as relative permeability and capillary pressures under different displacement paths, wettability and flow rates is essential in the study of subsurface flow processes [5].

Image-based methods require the availability of micro-computed tomography $(\mu-\mathrm{CT})$ or Xray based imaging facilities to obtain 3D image of the porous sample [6].

Andriamihaja S. et. al. [7] scanned carbonate rocks with X-Ray CT System. After scanning, the images were processed and then pore networks were extracted using several softwares. In order to understand fluid flow in complex porous media and to evaluate the impact of dissolution on fluid flow properties of the samples, Avizo ${ }^{\circledR}$ Fire software was used to simulate the permeability before and after rock dissolution. 
Authors of [8] used $\mu-\mathrm{CT}$ to image rock cuttings of sandstone and carbonate rock samples, extracted topologically equivalent networks from 3D $\mu-\mathrm{CT}$ images and constructed pore-scale network models to predict relative permeability and capillary pressure.

Laboratory experiments performed on core samples are time-consuming, labor-intensive and resource-intensive. Pore-network modeling (PNM) is less resource intensive. For the rational use of natural resources, PNM opens up the possibility of repeatedly carrying out various numerical experiments on the same core sample (injection of polymers, acid treatment, etc.).

This study is aimed to understand parameters controlling two-phase fluid flow at the pore scale (pore morphology and heterogeneity). The goal of this study is to calculate numerically effective porosity, average absolute permeability, capillary pressure, tortuosity, and relative permeability using pore-network models constructed using $\mu$-CT images.

Methods. Image processing and network extraction was accomplished using the Avizo ${ }^{\circledR}$ Software. One of the clearest and most effective methods for visualizing 3D image data is a direct volume rendering, it is a technique that provides a 3D representation of an entire dataset without segmentation. The basic model is based on the emission and absorption of light that is assigned to each voxel (3D pixel) of the volume. The algorithm simulates the propagation of light rays through the volume from predetermined sources. It determines how much light reaches each voxel on a beam and is emitted or absorbed by the voxel.

After the separation of the pore space, this data is used as input data for building a pore network model. The branches or endpoints of the network are called pores, and the lines connecting the pores are called throats. That is, the connections in the pore space are visualized by Avizo ${ }^{\circledR}$ as cylindrical throats, and the pores as spheres.

Rock samples. $\mu$-CT images of rock samples (input data for the PNM) were obtained from the open-access site of Imperial College London [9-14].

Table 1 shows image properties of some rock samples used in this paper (size of each sample is 1000 cubes).

Table 1 - Image properties of some rock samples

\begin{tabular}{cc}
\hline Sample & Resolution $(\boldsymbol{\mu m})$ \\
\hline Bentheimer sandstone & 3.0035 \\
\hline Doddington sandstone & 2.6929 \\
\hline Ketton carbonate & 3.00006 \\
\hline Carbonate C2 & 5.3
\end{tabular}

Figure 1 demonstrates 2D slices for following samples: carbonate $\mathrm{C} 2$, sandstone $\mathrm{S} 9$ and sand pack LV60C.
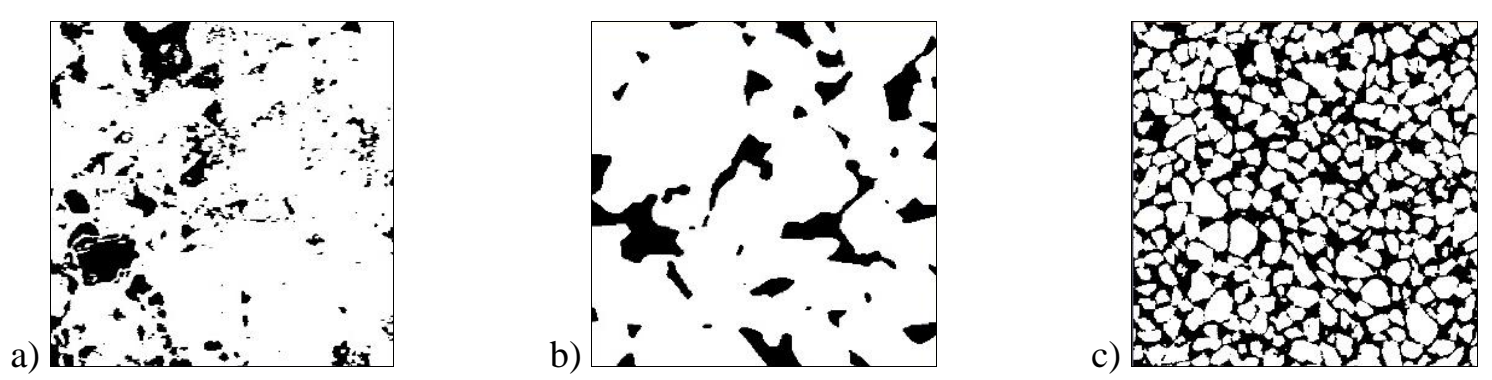

Figure 1. 2D slice of a) carbonate C2; b) sandstone S9; c) sand pack LV60C 
The volume rendering, pore space preparation and construction of pore-network models were performed using the Avizo ${ }^{\circledR}$ Software and demonstrated on Figures 2, 3, 4, 5, 6 and 7 for Bentheimer sandstone [9], Doddington sandstone [10], Ketton carbonate [11], carbonate C2 [12], sandstone S9 [13] and sand pack LV60C [14], respectively.

The two-phase code (pnflow) of Ali Q. Raeini [15] was used for the prediction of the effective porosity, absolute permeability, capillary pressure and relative permeabilities.
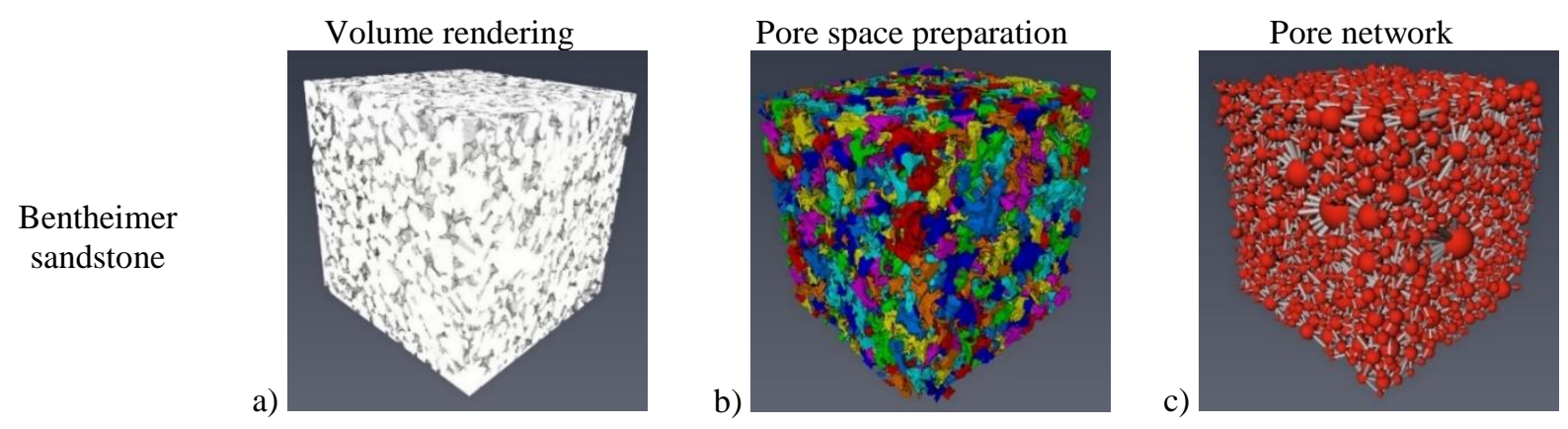

Figure 2. Volume rendering (a), pore space preparation (b) and pore network (c) for Bentheimer sandstone
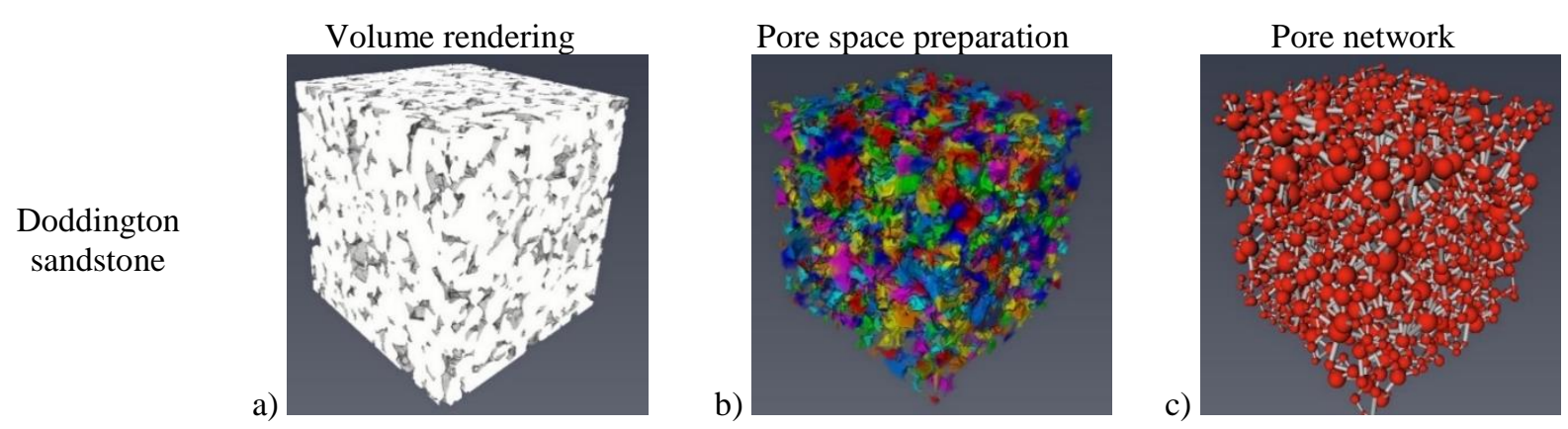

Figure 3. Volume rendering (a), pore space preparation (b) and pore network (c) for Doddington sandstone
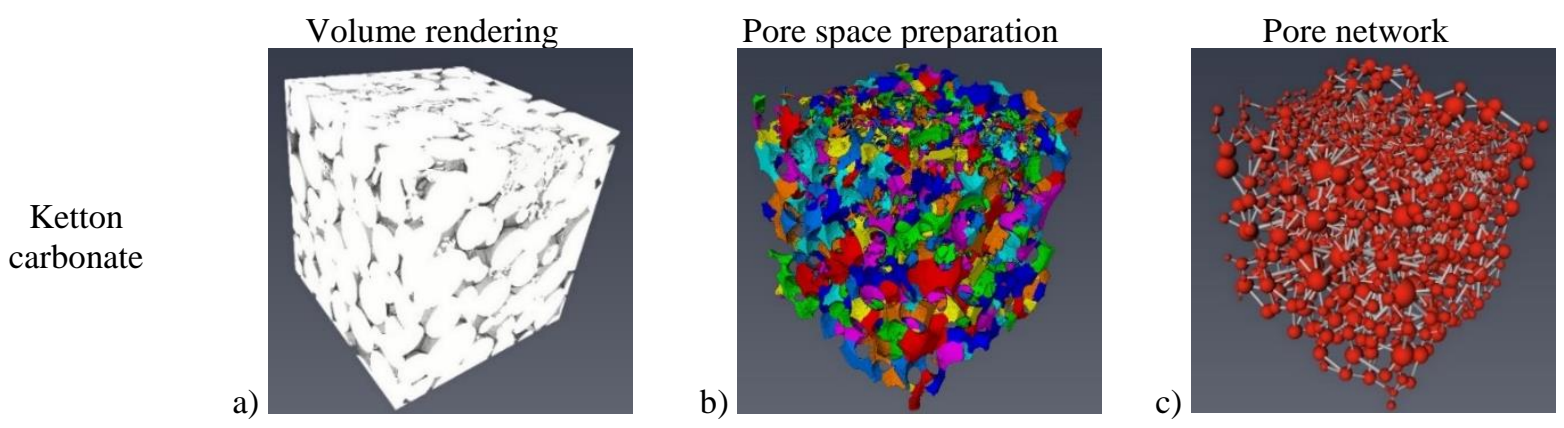

Figure 4. Volume rendering (a), pore space preparation (b) and pore network (c) for Ketton carbonate 

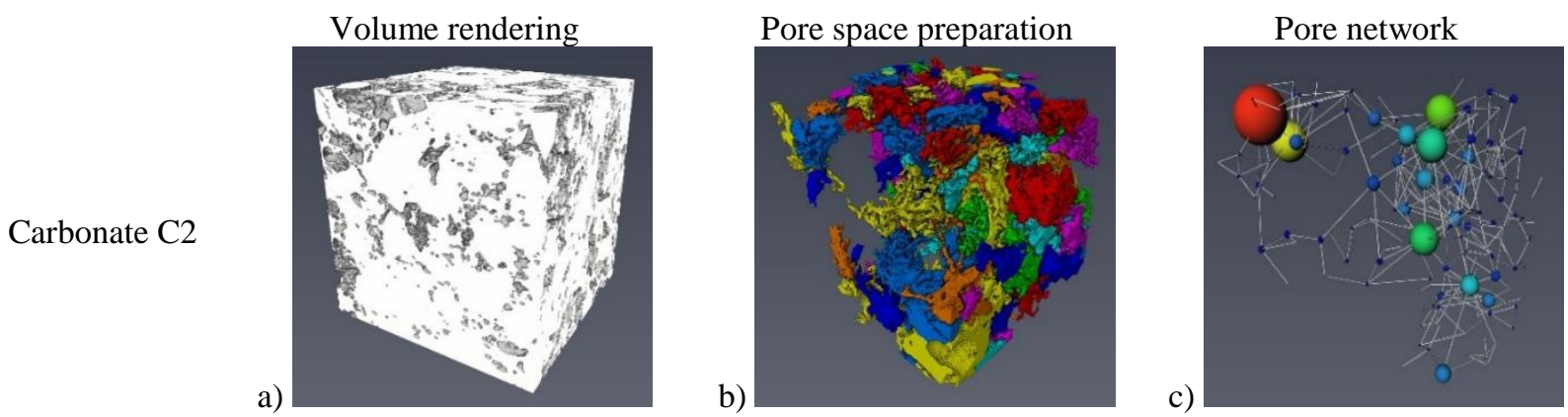

Figure 5. Volume rendering (a), pore space preparation (b) and pore network (c) for carbonate $\mathrm{C} 2$
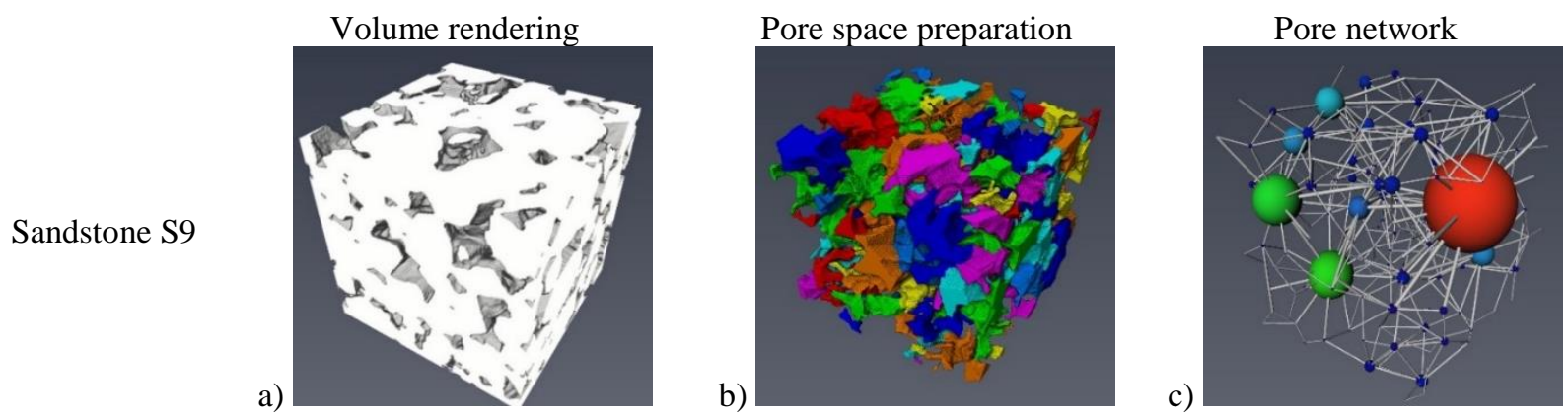

Figure 6. Volume rendering (a), pore space preparation (b) and pore network (c) for sandstone S9 (a-c)
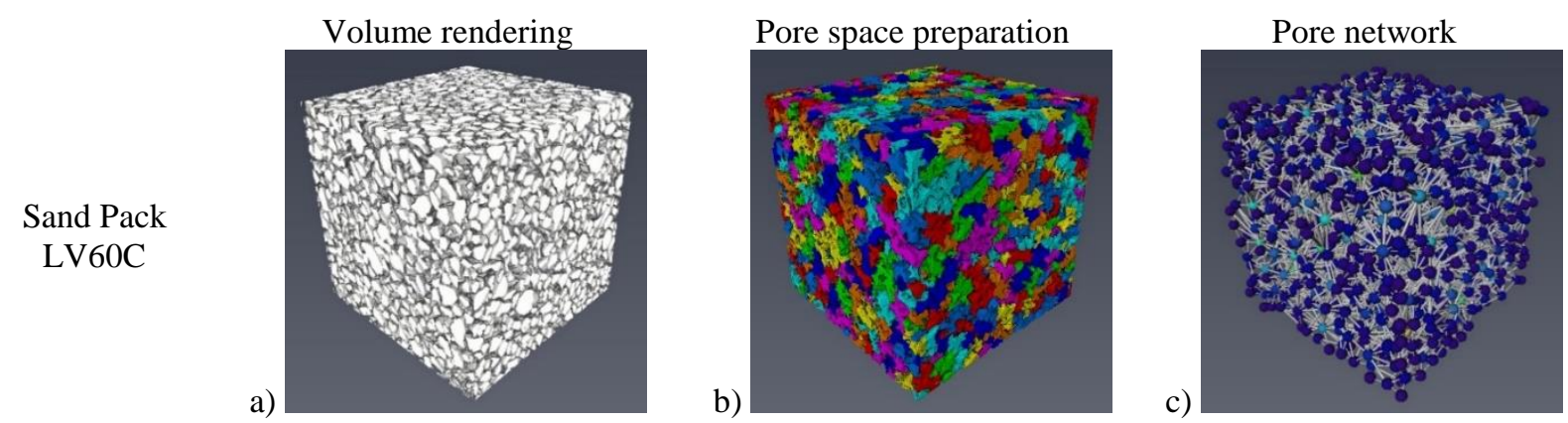

Figure 7. Volume rendering (a), pore space preparation (b) and pore network (c) for sand pack LV60C (a-c)

Gao Y. et. al. [16] used $\mu$-CT imaging and differential pressure measurements, and designed a comparative study to measure relative permeability and capillary pressure on the same reservoir sandstone sample under water-wet and mixed-wet conditions during steady-state waterflooding experiments. Relative permeabilities were calculated from the pressure differential measured during the experiment and the saturation calculated based on the images.

Alhammadi A.M. et. al. [17] used differential imaging X-ray microtomography combined with a steady-state flow apparatus to elucidate the displacement processes during the waterflooding. They measured relative permeability and capillary pressure on a carbonate rock sample and used the pore-scale images to measure the interfacial curvature from which the local capillary pressure was calculated. The relative permeability was calculated from the image-measured saturation, and the pressure differential across the sample. 
Basic equations. The absolute permeability $K$ of the network is calculated from the Darcy's law [18]:

$$
K=\frac{\mu_{p} q_{\mathrm{tsp}} L^{L}}{A \Delta P}
$$

where $\mu_{p}$ is the single-phase $p$ fluid viscosity; $q_{t s p}$ is the total single-phase flow rate; $L$ is the length; $A$ is the cross-sectional area; $\Delta P$ is the pressure drop.

Relative permeability $k_{r p}$ for network is calculated with:

$$
k_{r p}=\frac{q_{t m p}}{q_{t s p}}
$$

where $q_{t m p}$ is the total flow rate of phase $p$.

Numerical results. In this section results of calculation of rock and two-phase fluid flow properties are given. Tables 2 and 3 show results of calculation of the effective porosity and absolute permeability using the Avizo ${ }^{\circledR}$ and pnflow [15].

Table 2 - Effective porosity

\begin{tabular}{ccc}
\hline Sample & Avizo ${ }^{\circledR}$ & pnflow \\
\hline Bentheimer sandstone & 0.216262 & 0.221044 \\
\hline Doddington sandstone & 0.194798 & 0.199402 \\
\hline Ketton carbonate & 0.131819 & 0.136787 \\
\hline Carbonate C2 & 0.168 & 0.151552 \\
\hline Sandstone S9 & 0.222 & 0.224035 \\
\hline Sand Pack LV60C & 0.372 & 0.386034 \\
\hline
\end{tabular}

Table 3 - Absolute permeability

\begin{tabular}{ccc}
\hline Sample & Avizo ${ }^{\circledR}\left(\mathbf{m}^{2}\right)$ & pnflow $\left(\mathbf{m}^{\mathbf{2}}\right)$ \\
\hline Bentheimer sandstone & $3.54805 \times 10^{-12}$ & $2.55381 \times 10^{-12}$ \\
\hline Doddington sandstone & $3.76168 \times 10^{-12}$ & $2.93539 \times 10^{-12}$ \\
\hline Ketton carbonate & $7.3 \times 10^{-12}$ & $6.42765 \mathrm{e} \times 10^{-12}$ \\
\hline Carbonate C2 & $7.13871 \times 10^{-11}$ & $9.20592 \times 10^{-14}$ \\
\hline Sandstone S9 & $2.19491 \times 10^{-12}$ & $5.46587 \times 10^{-12}$ \\
\hline Sand Pack LV60C & $1.91463 \times 10^{-11}$ & $3.56241 \times 10^{-11}$ \\
\hline
\end{tabular}

As it can be seen from Tables 2 and 3 the difference between the two calculations is negligible, except the absolute permeability of carbonate C2. Table 4 demonstrates results of calculation of the tortuosity in 3 directions using the Avizo ${ }^{\circledR}$.

Table 4 - Tortuosity in 3 directions

\begin{tabular}{cccc}
\hline Sample & \multicolumn{3}{c}{ Direction } \\
\cline { 2 - 4 } & $\mathbf{x}$ & $\mathbf{y}$ & $\mathbf{z}$ \\
\hline Carbonate C2 & 1.63 & 1.86 & 1.49 \\
\hline Sandstone S9 & 1.64 & 1.68 & 1.64 \\
\hline Bentheimer sandstone & 1.61 & 1.59 & 1.68 \\
\hline Sand Pack LV60C & 1.52 & 1.58 & 1.53 \\
\hline Doddington sandstone & 1.66 & 1.67 & 1.8 \\
\hline Ketton carbonate & 1.58 & 1.66 & 1.80 \\
\hline
\end{tabular}

The pore size distribution, comparison of relative permeability and capillary pressure curves for drainage and imbibition are demonstrated on Figures 8, 9, 10, 11, 12 and 13 for Bentheimer sandstone, Doddington sandstone, Ketton carbonate, carbonate $\mathrm{C} 2$, sandstone $\mathrm{S} 9$ and sand pack LV60C, respectively. 
In the figures $k_{r w}$ and $k_{r o}$ are the relative permeability of water and oil, respectively, and $P_{c}$ is the capillary pressure.

a)

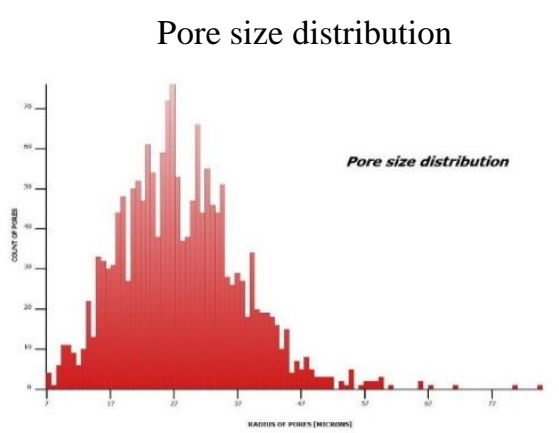

b)

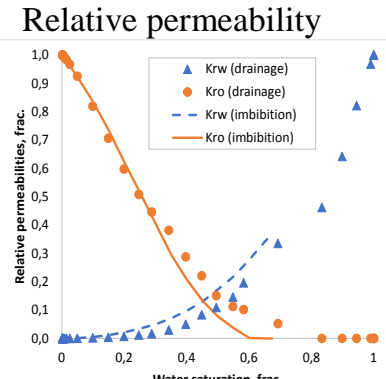

Drainage and imbibition

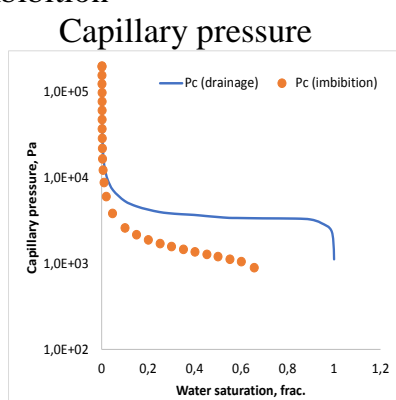

c)

Figure 8. Pore size distribution (a), relative permeabilities (b) and capillary pressure (c) curves for drainage (dots) and imbibition (lines) for Bentheimer sandstone

Pore size distribution

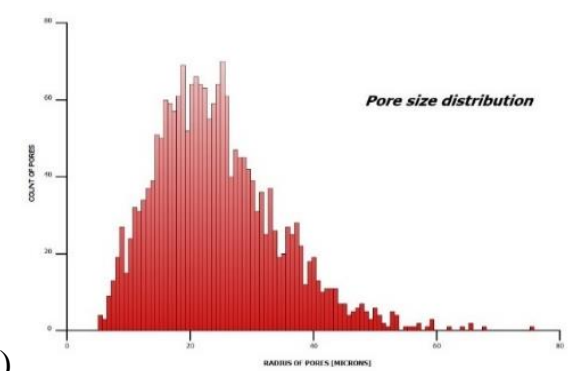

Drainage and imbibition

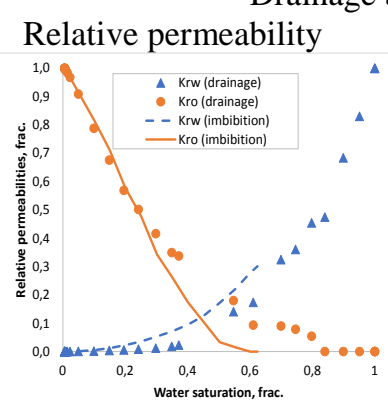

c)

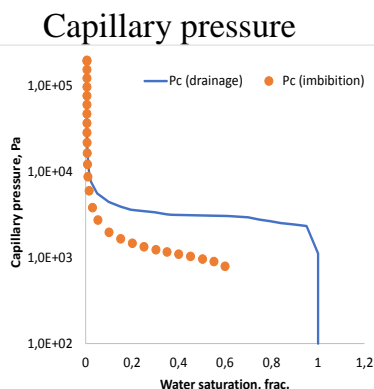

Figure 9. Pore size distribution (a), relative permeabilities (b) and capillary pressure (c) curves for drainage (dots) and imbibition (lines) for Doddington sandstone

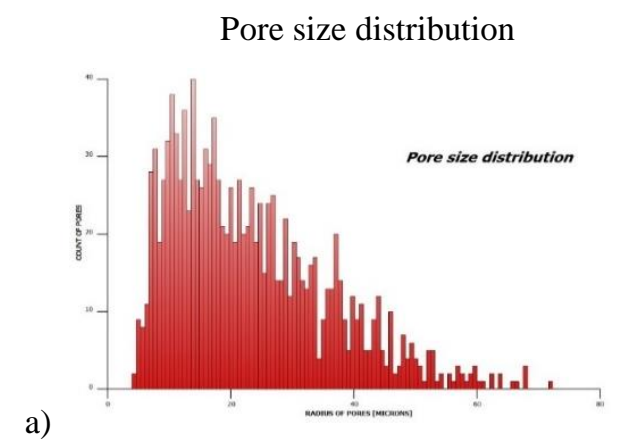

b)

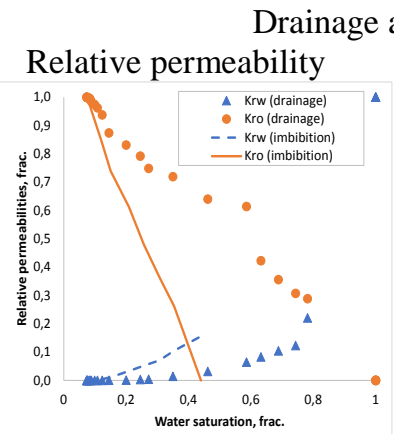

c)

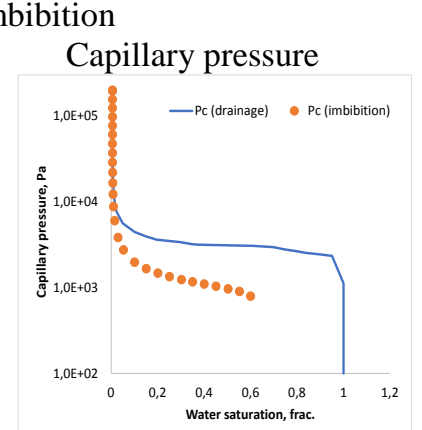

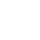

Figure 10. Pore size distribution (a), relative permeabilities (b) and capillary pressure (c) curves for drainage (dots) and imbibition (lines) for Ketton carbonate 


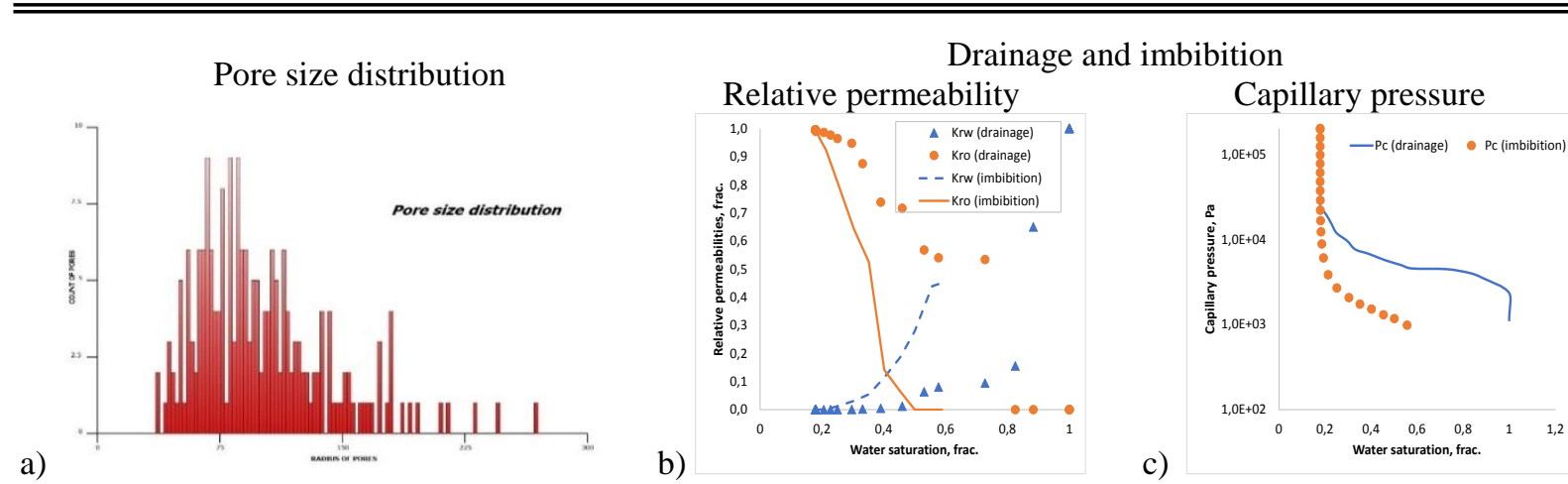

a)

Figure 11. Pore size distribution (a), relative permeabilities (b) and capillary pressure (c) curves for drainage (dots) and imbibition (lines) for carbonate C2 a)

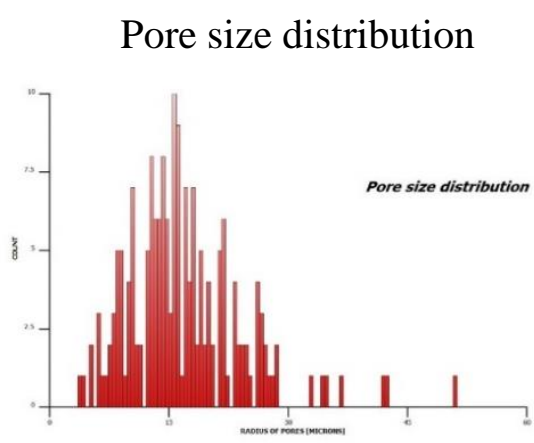

b)

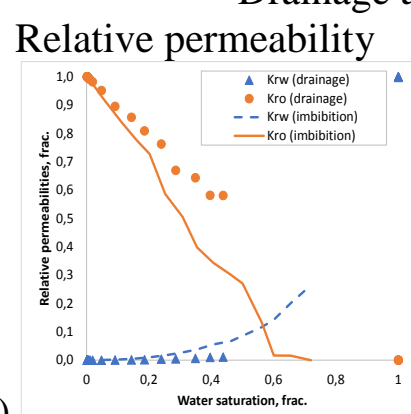

c)

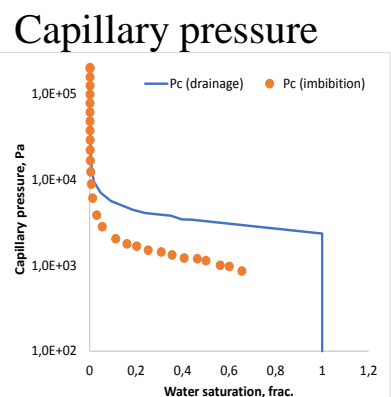

Figure 12. Pore size distribution (a), relative permeabilities (b) and capillary pressure (c) curves for drainage (dots) and imbibition (lines) for sandstone S9

Pore size distribution

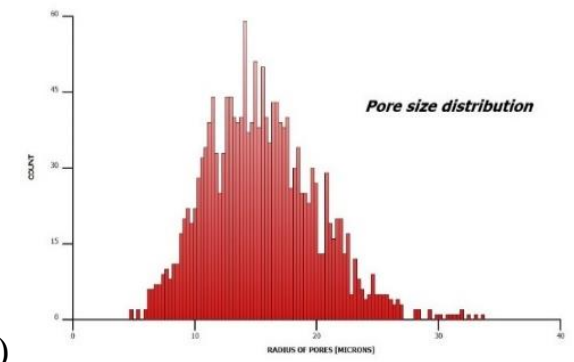

b)

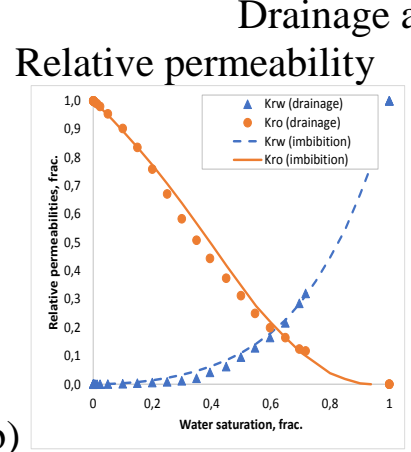

c)

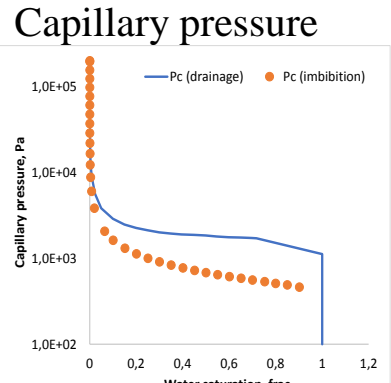

Figure 13. Pore size distribution (a), relative permeabilities (b) and capillary pressure (c) curves for drainage (dots) and imbibition (lines) for sand pack LV60C

Conclusion. The pore network modeling (PNM) is a well-established approach for the multiphase fluid flow simulation in porous materials. The pore-scale modeling combined with geologically realistic networks can reliably predict properties of one-phase and two-phase fluid flow without conducting time-consuming physical experiments. The advance of PNM is that it requires less computer power than direct numerical simulation.

In this paper PNM using volume rendering of rock $\mu$-CT images and pore space preparation were performed using the Avizo ${ }^{\circledR}$ Software. We successfully predict effective porosity, absolute permeability, relative permeability, capillary pressure and tortuosity. Also, calculation results of effective porosity and permeability using the Avizo ${ }^{\circledR}$ and pnflow [15] are compared. The difference is negligible. 
Acknowledgements. This research is funded by the Science Committee of the Ministry of Education and Science of the Republic of Kazakhstan (Grant No. AP08052055), which is gratefully acknowledged by the authors.

\section{REFERENCES}

[1] Joekar-Niasar V., van Dijke M.I.J., Hassanizadeh S.M. "Pore-scale modeling of multiphase flow and transport: achievements and perspectives". Tranp Porous Med. 94 (2012): 461-464. https://doi.org/10.1007/s11242-012-0047-4.

[2] Valvante P.H., Blunt M.J. "Predictive pore-scale network modeling". Proceedings of SPE Annual Technical Conference and Exhibition. (2003) https://doi.org/10.2523/84550-ms.

[3] Guibert R., Nazarova M., Horgue P., Hamon G., Creux P., Debenest G. "Computational permeability determination from pore-scale imaging: sample size, mesh and method sensitivities". Trans Porous Med. 107 (2015): 641-656. https://doi.org/10.1007/s11242-015-0458-0.

[4] Akasheva Zh., Assilbekov B., Kudaikulov A., Beisembetov I. "Numerical calculation of relative phase permeabilities for two-phase flow in the channel". Materials Today: Proceedings, 25 (2020): 52-57. https://doi.org/10.1016/j.matpr.2019.11.101.

[5] Raeini A.Q., Yang J., Bondino I, Bultreys T., Blunt M.J., Bijeljic B. "Validating the Generalized Pore Network Model Using Micro-CT Images of Two-Phase Flow". Transp Porous Med. 130 (2019): 405-424. https://doi.org/10.1007/s11242-019-01317-8.

[6] Sharqawy M.H. "Construction of pore network models for Berea and Fontainebleau sandstones using non-linear programing and optimization techniques". Advances in Water Res., 98 (2016): 198-210. https://doi.org/10.1016/j.advwatres.2016.10.023.

[7] Andriamihaja S., Padmanabhan E., Ben-Awuah J., Sokkalingam R. "Static dissolution-induced 3D pore network modification and its impact on critical pore attributes of carbonate rocks". Petrol. Explor. Develop., 46(2) (2019): 374-383. https://doi.org/10.1016/S1876-3804(19)60017-0.

[8] Dong H., Touati M., Blunt M.J. "Pore Network Modeling: Analysis of Pore Size Distribution of Arabian Core Samples." SPE Middle East Oil and Gas Show and Conference, (2007). SPE-105156-MS https://doi.org/10.2118/105156-MS.

[9] Bentheimer sandstone image. https://imperialcollegelondon.app.box.com/v/iccpsimbentheimer2015.

[10] Doddington sandstone image. https://imperialcollegelondon.app.box.com/v/iccpsimdoddington2015.

[11] Ketton carbonate image. https://imperialcollegelondon.app.box.com/v/iccpsim-ketton2015.

[12] Carbonate C2 image. https://www.imperial.ac.uk/earth-science/research/research-groups/porescale-modelling/micro-ct-images-and-networks/carbonate-c2/.

[13] Sandstone S9 image. https://www.imperial.ac.uk/earth-science/research/research-groups/porescale-modelling/micro-ct-images-and-networks/sandstone-s $9 /$.

[14] Sand pack LV60C image. https://www.imperial.ac.uk/earth-science/research/researchgroups/pore-scale-modelling/micro-ct-images-and-networks/sand-pack-lv60c/.

[15] Pnflow simulation code. https://github.com/aliraeini/pnflow.

[16] Gao Y., Raeini A.Q., Selem A.M., Bondino I., Blunt M.J., Bijeljic B. "Pore-scale imaging with measurement of relative permeability and capillary pressure on the same reservoir sandstone sample under water-wet and mixed-wet conditions". Advances in Water Res. (2020), 103786. https://doi.org/10.1016/j.advwatres.2020.103786.

[17] Alhammadi A.M., Gao Y., Akai T., Blunt M.J., Bijeljic B. "Pore-scale X-ray imaging with measurement of relative permeability, capillary pressure and oil recovery in a mixed-wet micro-porous carbonate reservoir rock". Fuel, 268 (2020), 117018. https://doi.org/10.1016/j.fuel.2020.117018.

[18] Valvante P.H., Blunt M.J. "Predictive pore-scale modeling of two-phase flow in mixed wet media". Wat. Resources Research, 40 (2004) W07406, https://doi.org/10.1029/2003WR002627. 


\title{
${ }^{1}$ Ж.К. Акашева*, ${ }^{1,2}$ Д.Ә. Болысбек, ${ }^{1}$ Б.К. Асилбеков, ${ }^{1,2}$ А.К. Ергеш, ${ }^{1,2}$ А.Е. Жансейт \\ ${ }^{1}$ Satbayev University, Алматы, Қазақстан \\ 2əл-Фараби атындағы Қазақ ұлттық университеті, Алматы, Қазақстан \\ *e-mail: zhibek_akasheva@mail.ru \\ КЕУЕК-ЖЕЛІЛІК МОДЕЛЬДЕУ ЖӘНЕ ТАУ ЖЫНЫСЫ МЕН ЕКІ-ФАЗАЛЫ СҰЙВК АҒЫСЫНЫҢ ҚАСИЕТТЕРІН АНЫҚТАУ
}

Андатпа. Мұнай саласында кеуек масштабында модельдеу кеңінен қолданылуда. Кеуек масштабында визуализация жасау және модельдеудің мақсаты - кеуекті ортадағы көпфазалы ағынның қасиеттерін болжау болып табылады. Бұл жұмыста геологиялық керн үлгілердің кеуекті-желілік моделін құрылды және тау жыныстары мен екі фазалы сұйықтық ағынының қасиеттері анықталды. Кеуектіжелілік модельдері әртүрлі тау жыныстарының үлгілерінің микро-компьютерлік томографиялық суреттерін қолдану арқылы жасалды. Кеуектілік, орташа абсолютті өткізгіштік, капиллярлық қысым, кисықтығы (3 бағытта) және салыстырмалы өткізгіштік ығысудың 2 түрі (дренаж және сіңу) бойынша есептелген. тау жыныстарының үлгілерін визуализациялау үшін және тау жыныстары мен екі фазалы сұйықтық ағындарының қасиеттерін есептеу үшін Avizo® бағдарламасы және екі фазалық код пайдаланылды, өйткені бұл петрофизикалық қасиеттерді болжау үшін құнды және сенімді құрал болып табылады және кеуек кеңістігін көрнекі түрде дамытады. Микрокомпьютерлік томографияны сканерлеу деректері негізінде жасалған негізгі керн үлгілерінің 3D модельдері мұнай және мұнай кен орындарына қызмет көрсететін компанияларға физикалық керн үлгілерін қоймаларда сақтаудың орнына компьютерде сандық керн үлгілеріне мәліметтер базасын құруға мүмкіндік береді, бұл өз кезегінде одан әрі жұмыс істеу үшін керн үлгілеріне қол жеткізуді едәуір жеңілдетеді.

Негізгі сөздер: кеуекті-желілік моделі, тікелей сандық модельдеу, микро-компьютерлік томография, кеуектілік, абсолютті өткізгіштік, салыстырмалы өткізгіштік, кеуектің мөлшері бойынша таралуы, қисықтылығы, капиллярлық қысым.

\author{
${ }^{1}$ Ж.К. Акашева*, ${ }^{1,2}$ Д.Ә. Болысбек, ${ }^{1}$ Б.К. Асилбеков, ${ }^{1,2}$ А.К. Ергеш, ${ }^{1,2}$ А.Е. Жансейт \\ ${ }^{1}$ Satbayev University, Алматы, Казахстан \\ ${ }^{2}$ Казахский национальный университет им. аль-Фараби, Алматы, Казахстан \\ *e-mail: zhibek_akasheva@mail.ru
}

\section{ПОРОМАСШТАБНОЕ МОДЕЛИРОВАНИЕ И ОПРЕДЕЛЕНИЕ СВОЙСТВ ГОРНЫХ ПОРОД И ДВУХФАЗНОГО ТЕЧЕНИЯ ФЛЮИДОВ}

\begin{abstract}
Аннотация. Моделирование в масштабе пор широко применяется в нефтяной промышленности. Целью построения изображений и моделирования в масштабе пор является прогнозирование свойств многофазного потока в пористой среде. Построение модели поровой сети для геологически реалистичных образцов и определение свойств горных пород и потока двухфазных флюидов описаны и обсуждаются в этой статье. Модели поровой сети были построены с использованием опубликованных изображений микрокомпьютерной томографии различных образцов горных пород. Эффективная пористость, средняя абсолютная проницаемость, капиллярное давление, извилистость (в 3 направлениях) и относительная проницаемость были рассчитаны для 2 типов вытеснения (дренаж и пропитывание). Программное обеспечение Avizo® и двухфазный код использовались для объемного рендеринга образцов горных пород и расчетов свойств горных пород и потока двухфазных флюидов. так как это ценный и надежный инструмент для прогнозирования петрофизических свойств и достижения в визуализации порового пространства. Созданные трехмерные модели образцов керна на основе данных сканирования с микрокомпьютерной томографии позволят нефтесервисным компаниям создавать цифровые базы данных кернов на компьютере вместо хранения физических кернов на складах, что, в свою очередь, значительно облегчает доступ к кернам для дальнейшей работы с ними.

Ключевые слова: поросетевая модель, прямое численное моделирование, микрокомпьютерная томография, пористость, абсолютная проницаемость, относительная проницаемость, распределение пор по размерам, извилистость, капиллярное давление.
\end{abstract}

